\title{
IDENTIFIKASI FAKTOR-FAKTOR PENYEBAB ALIH FUNGSI LAHAN SAWAH MENJADI NON SAWAH DI KECAMATAN TOMPASOBARU KABUPATEN MINAHASA SELATAN
}

\author{
Rendy Christian Laoh \\ Theodora M. Katiandagho \\ Celsius Talumingan
}

\begin{abstract}
This study aims to identify factors causing the conversion of wetland to non-rice field in Tompaso Baru Sub-district of South Minahasa Regency. This research was conducted for 3 months from December 2017 until January 2018. The data used in this research are primary data and secondary data. Primary data was optained from interview to respondent, while secondary data was optained from Tompaso Baru District office and BP4K. The result of the research shows the factors causing the conversion of rice field in Tompaso Baru sub-district of South Minahasa Regency are economic factors (low farm income, land selling price), policy, and availability of water. *ghmk*.
\end{abstract}

Keywords: conversion of wetland to non-rice, Tompaso Baru Sub-district, South Minahasa Regency

\begin{abstract}
ABSTRAK
Penelitian ini bertujuan untuk mengidentifikasi faktor-faktor penyebab alih fungsi lahan sawah menjadi non-sawah di Kecamatan Tompaso Baru Kabupaten Minahasa Selatan. Penelitian ini dilakukan selama 3 bulan sejak Desember 2017 hingga Januari 2018. Data yang digunakan dalam penelitian adalah data primer dan data sekunder. Data primer diperoleh dari wawancara kepada responden, sedangkan data sekunder diperoleh dari Kantor Kecamatan Tompaso Baru dan BP4K. Hasil penelitian yang diperoleh menunjukkan factor-faktor penyebab alih fungsi lahan sawah di Kecamatan Tompaso Baru Kabupaten Minahasa Selatan adalah faktor ekonomi (rendahnya pendapatan usahatani, harga jual lahan), kebijakan, ketersediaan air. "ghmk*.
\end{abstract}

Kata kunci: alih fungsi lahan sawah, Kecamatan Tompaso Baru, Kabupaten Minahasa Selatan

\section{PENDAHULUAN}

\section{Latar Belakang}

Indonesia merupakan salah-satu negara berkembang, dimana sektor pertanian memegang peranan penting dalam perekonomian. Hal ini disebabkan karena ketersediaan sumberdaya lahan pertanian yang sangat luas, baik lahan persawahan maupun lahan perkebunan.

Lahan sawah merupakan salah satu aset yang sangat penting dalam pembangunan pertanian. Alasannya, di karenakan peranannya dalam mendukung ketahanan pangan. Masyarakat Indonesia yang mayoritas pendudukunya mengkonsumsi beras sebagai makanan pokok, membuat ketersediaan beras sangatlah penting. Sehingga lahan sawah sebagai media untuk memproduksi beras sangat diperlukan keberadaannya. Selain alasan tersebut, biaya untuk mencetak lahan sawah baru beririgasi cukup besar yaitu sekitar Rp.8.900.000/hektar sampai Rp.13.500.000 /hektar (Direktorat Jenderal Prasarana dan Sarana Pertanian 2013), serta waktu yang cukup lama untuk mencetak lahan sawah. 
Seiring dengan cepatnya pertumbuhan penduduk dan ekonomi setiap tahunnya, menyebabkan kebutuhan akan lahan semakin meningkat. Pertumbuhan penduduk dan perekonomian yang cepat, meningkatkan pula kebutuhan lahan non-pertanian, sementara luas lahan relatif tetap. Sehingga untuk mengatasi kebutuhan lahan non-pertanian, terjadilah alih fungsi lahan.

Lestari (dalam Saleh, dkk 2012), mendefinisikan alih fungsi lahan sawah atau lazimnya disebut sebagai konversi lahan adalah perubahan fungsi sebagian atau seluruh kawasan lahan dari fungsinya semula (seperti yang direncanakan) menjadi fungsi lain yang berdampak negatif (masalah) terhadap lingkungan dan potensi lahan itu sendiri.

Alih fungsi sawah yang semakin banyak terjadi di berbagai daerah dapat memberikan dampak pada menurunnya jumlah produksi beras, menurunnya pendapatan petani, dan dapat meningkatkan angka kemiskinan. Hal ini sesuai dengan yang dikatakan oleh Sudaryanto (dalam Hidayati dan Kinseng 2013), mengatakan bahwa dampak negatif konversi lahan sawah adalah degradasi daya dukung ketahanan pangan nasional dan meningkatnya kemiskinan. Sama halnya dengan yang dikatakan Irawan dan Prayitno (2012) dalam Sunartomo (2015), kegiatan konversi lahan sawah cenderung menimbulkan penurunan produksi per satuan lahan yang semakin besar dari tahun ke tahun.

Alih fungsi lahan (khususnya lahan sawah) bukanlah hal baru, tetapi telah menjadi masalah serius yang telah terjadi diberbagai daerah. Persawahan yang memiliki fungsi utama sebagai penyedia bahan pangan, ketika dialihkan fungsinya, sangatlah sulit dikembalikan ke fungsi asalnya, karena rusaknya berbagai sarana penunjangnya. Berarti, alih fungsi lahan sawah akan bersifat permanen.

Kecamatan Tompaso Baru merupakan daerah yang memiliki ketersediaan lahan pertanian yang luas. Hal tersebut membuat sebagian besar masyarakatnya bermata pencaharian utama disektor pertanian khususnya sawah. Namun, seiring dengan perkembangan dari tahun ketahun, menyebabkan lahan sawah yang ada kini mulai berkurang akibat alih fungsi yang banyak terjadi. Luas lahan sawah di Kecamatan Tompaso Baru dapat dilihat pada Tabel 1.

\begin{tabular}{ccc} 
Tabel 1. & $\begin{array}{c}\text { Luas Lahan Sawah Kecamatan Tompaso Baru } \\
\text { Tahun 2012 - 2016 }\end{array}$ & Luas Lahan Sawah (Ha) \\
\hline No & Tahun & 853,5 \\
\hline 1 & 2012 & 850 \\
2 & 2013 & 839,5 \\
3 & 2014 & 832,5 \\
4 & 2015 & 826 \\
5 & 2016 & \\
\hline
\end{tabular}

Sumber : BP3K Kecamatan Tompaso Baru

Sejak tahun 2012 hingga tahun 2016, lahan sawah di Kecamatan Tompaso Baru telah berkurang seluas 27,5 hektar.

Pertumbuhan penduduk yang cepat menyebabkan kebutuhan lahan untuk pemukiman semakin meningkat, sehingga mendorong pada terjadinya alih fungsi lahan sawah menjadi lahan pemukiman. Selain itu, modernisasi yang terjadi saat ini berdampak pada sikap petani yang berusaha ingin meningkatkan kualitas hidup mereka karena mereka beranggapan bahwa bertani sawah sudah tidak menguntungkan lagi, sehingga mereka memilih beralih pekerjaan dari petani sawah ke sektor usaha lain seperti industri, budidaya ikan, dan usaha lain yang dianggap lebih menguntungkan. Akibatnya, lahan yang semula digunakan untuk lahan sawah beralih fungsi penggunaanya.

\section{Rumusan Masalah}

Berdasarkan uraian latar belakang, maka yang menjadi masalah dalam penelitian ini adalah apakah penyebab alih fungsi lahan sawah di Kecamatan Tompaso Baru?

\section{Tujuan Penelitian}

Tujuan penelitian ini adalah untuk mengidentifikasi faktor-faktor penyebab alih fungsi lahan sawah ke non-sawah di Kecamatan Tompaso Baru Kabupaten Minahasa Selatan.

\section{Manfaat Penelitian}

1. Penelitian ini diharapkan dapat dijadikan bahan acuan untuk menanggulangi alih fungsi lahan sawah yang terjadi di Kecamatan Tompaso Baru Kabupaten Minahasa Selatan.

2. Penelitian ini juga dapat menjadi referensi untuk penelitian-penelitian serupa. 


\section{METODE PENELITIAN}

\section{Waktu Dan Tempat Penelitian}

Penelitian ini dilaksanakan selama 3 bulan yaitu dari bulan Desember 2016 sampai Febuari 2017 mulai dari persiapan sampai penyususnan laporan penelitian. Penilitian ini dilaksanakan di Kecamatan Tompasobaru Kabupaten Minahasa Selatan.

\section{Metode Pengumpulan Data}

Dalam penelitian ini menggunakan data primer yang diperoleh dari wawancara langsung dengan responden dengan menggunakan daftar pertanyaan yang telah disiapkan. Serta data sekunder yang diperoleh dari instansi terkait.

\section{Metode Pengambilan Sampel}

Populasi petani yang mengalih fungsikan sebagian ataupun seluruh lahan sawah miliknya dengan jumlah 42 orang. Sementara sampel yang di ambil adalah keseluruhan populasi tersebut, yakni 42 orang (sampel jenuh).

\section{Konsep Pengukuran Variabel}

Variabel-variabel yang akan diukur dalam penelitian ini yaitu:

1. Karakteristik Responden
a. Nama
b. Umur (Tahun)
c. Pendidikan
d. pekerjaan

2. Faktor Ekonomi
a. Pendapatan
b. Harga Jual Lahan

3. Kebijakan

4. Ketersediaan Air

\section{Analisis Data}

Analisis yang digunakan dalam penelitian ini adalah analisis deskriptif untuk menggambarkan faktor-faktor penyabab terjadinya alih fungsi lahan sawah di Kecamatan Tompaso baru Kabupaten Minahasa Selatan.

\section{HASIL DAN PEMBAHASAN}

\section{Deskripsi Lokasi Penelitian}

\section{Keadaan Geografis Lokasi Penelitian}

Kecamatan Tompaso Baru adalah salah satu kecamatan di Kabupaten Minahasa Selatan. Secara geografis kecamatan Tompaso Baru memiliki batas - batas wilayah sebagai berikut:

- Sebelah Utara berbatasan dengan Kecamatan Ranoyapo

- Sebelah Timur berbatasan dengan Kabupaten Bolaang Mongondow Timur

- Sebelah Selatan Berbatasan dengan Kecamatan Maesaan

- Sebelah Barat Berbatasan dengan Kabupaten Bolaang Mongondow

Kecamatan Tompaso Baru terletak pada ketinggian 368 meter diatas permukaan laut. Kecamatan Tompaso Baru memiliki 10 desa, dengan luas wilayah keseluruhan adalah 129,81 $\mathrm{km}^{2}$. Desa terluas adalah desa Liandok dengan luas $75 \mathrm{~km}^{2}$ dan desa terkecil adalah desa Tompaso Baru Satu dengan luas $0,85 \mathrm{~km}^{2}$.

\begin{tabular}{clcr} 
Tabel 2. Luas Wilayah Kecamatan Tompaso Baru \\
\hline No & \multicolumn{1}{c}{ Desa } & $\begin{array}{c}\text { Luas Wilayah } \\
\left(\mathbf{K m}^{2}\right)\end{array}$ & Persentase (\%) \\
\hline 1 & Liandok & 75,00 & 57,78 \\
2 & Kinalawiran & 14,87 & 11,46 \\
3 & Karowa & 9,20 & 7,09 \\
4 & Pinaesaan & 8,00 & 6,16 \\
5 & Raratean & 6,15 & 4,74 \\
6 & Torout & 5,69 & 4,38 \\
7 & Tompaso Baru Dua & 4,50 & 3,47 \\
8 & Sion & 4,20 & 3,24 \\
9 & Lindangan & 1,35 & 1,04 \\
10 & Tompaso Baru Satu & 0,85 & 0,65 \\
\hline \multicolumn{5}{c}{ Jumlah } & 129,81 & 100 \\
\hline Sumber $:$ Kantor Kecamatan Tompaso Baru
\end{tabular}

\section{Keadaan Penduduk}

Jumlah penduduk yang ada di Kecamatan Tompaso Baru adalah 12.588 jiwa. Jumlah penduduk di Kecamatan Tompaso Baru Menurut desa dapat dilihat pada Tabel 3.

\begin{tabular}{clc}
\multicolumn{2}{c}{ Tabel 3. Jumlah Penduduk Menurut Desa Tahun 2017} \\
\hline No & \multicolumn{1}{c}{ Desa } & Jumlah Penduduk (Jiwa) \\
\hline 1 & Tompaso Baru Satu & 2.199 \\
2 & Tompaso Baru Dua & 1.820 \\
3 & Torout & 1.510 \\
4 & Pinaesaan & 1.439 \\
5 & Karowa & 1.321 \\
6 & Sion & 1.119 \\
7 & Kinalawiran & 1.070 \\
8 & Raratean & 934 \\
9 & Liandok & 624 \\
10 & Lindangan & 552 \\
\hline \multicolumn{3}{c}{ Jumlah } \\
\hline \multicolumn{3}{c}{ Sumber: Kantor Kecamatan Tompaso Baru } \\
\end{tabular}




\section{Karakteristik Responden}

Karakteristik responden dalam penelitian ini adalah umur, tingkat pendidikan, pekerjaan.

\section{Umur}

Umur dapat mempengaruhi cara berpikir dan produktifitas seseorang dalam bekerja. Berdasarkan penelitian yang dilakukan di Kecamatan Tompaso Baru, umur responden dapat dilihat pada Tabel 4.

\begin{tabular}{lllc}
\multicolumn{4}{l}{ Tabel 4. Jumlah Responden Menurut Tingkat Umur } \\
\hline No & $\begin{array}{c}\text { Umur } \\
\text { (Tahun) }\end{array}$ & $\begin{array}{c}\text { Jumlah } \\
\text { Responden }\end{array}$ & Persentase (\%) \\
\hline 1 & $30-64$ & 29 & 69,05 \\
2 & $>64$ & 13 & 30,95 \\
\hline & Jumlah & 42 & 100,00 \\
\hline
\end{tabular}

Sumber : Diolah dari data primer 2017

Tabel 4, menunjukkan bahwa sebagian besar responden berada pada usia produktif, yaitu sebanyak $69,05 \%$. Sementara $30,95 \%$ berada pada usia tidak produktif.

\section{Tingkat Pendidikan}

Tingkat pendidikan seseorang dapat mempengaruhi tingkah laku seseorang dalam pekerjaan. Berdasarkan penelitian, tingkat pendidikan responden dapat dilihat pada Tabel 5.

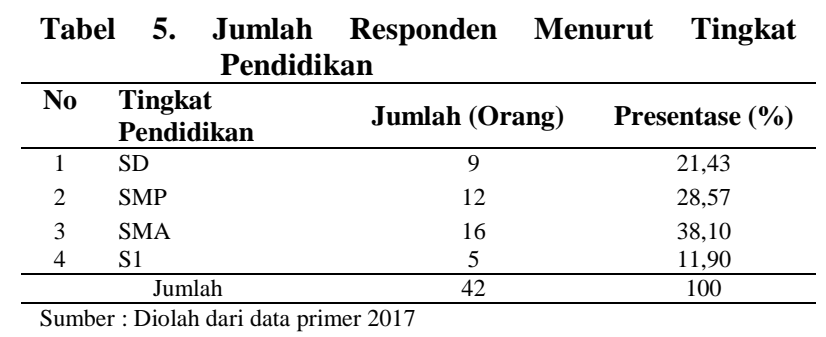

Tabel 5 menunjukkan bahwa sebagian besar responden adalah lulusan Sekolah Menengah Atas (SMA) yaitu sebanyak 16 orang responden $(38,10 \%)$. Sementara jumlah yang paling sedikit adalah responden yang berpendidikan S1.

\section{Pekerjaan}

Berdasarkan penelitian yang dilakukan di Kecamatan Tompaso Baru, pekerjaan responden dapat di lihat pada Tabel 6.

\begin{tabular}{clcr}
\multicolumn{6}{c}{ Tabel 6. Jumlah Reponden Menurut Pekerjaan } \\
\hline No & Pekerjaan & Jumlah (Orang) & Persentase (\%) \\
\hline 1 & Petani & 29 & 69,05 \\
2 & Pengusaha & 10 & 23,81 \\
3 & Guru & 1 & 2,38 \\
4 & Pendeta & 1 & 2,38 \\
5 & Pensiunan & 1 & 2,38 \\
\hline \multicolumn{5}{l}{ Sumber $:$ Diolah dari data primer 2017} \\
\end{tabular}

\section{Alih Fungsi Lahan Sawah di Kecamatan Tompaso Baru}

Alih fungsi lahan sawah yang terjadi di Kecamatan Tompaso Baru dapat dilihat pada Tabel 7.

\begin{tabular}{llcrcr}
\multicolumn{6}{c}{ Tabel 7. Alih Fungsi Lahan Sawah ke Fungsi Lain Menurut Luas Lahan } \\
\hline \multicolumn{5}{c}{ Luas Lahan } & \multicolumn{3}{c}{ Jumlah Responden } \\
\hline No & Fungsi Lain & Luas (Ha) & Persentase (\%) & $\begin{array}{l}\text { Jumlah } \\
\text { (Oran) }\end{array}$ & Persentase (\% \\
\hline 1 & Ladang & 16,95 & 61,64 & 24 & 57,14 \\
2 & Pemukiman & 5,1 & 18,55 & 8 & 19,05 \\
3 & Kolam ikan & 2,4 & 8,73 & 6 & 14,29 \\
4 & Penggilingan & 2,05 & 7,45 & 3 & 7,14 \\
5 & padi & 1 & 3,64 & 1 & 2,38 \\
\hline Jumlah & 27,5 & 100 & 42 & 100 \\
\hline \multicolumn{5}{r}{ Sumber : Diolah dari data primer 2017 } \\
\multicolumn{7}{l}{}
\end{tabular}

Tabel 7 menunjukkan bahwa lahan sawah di Kecamatan Tompaso Baru sebagian besar dialih fungsikan menjadi ladang yakni seluas 16,95 hektar atau $61,64 \%$ dari luas keseluruhan lahan sawah yang dialih fungsikan.

\section{Faktor-Faktor Penyebab Terjadinya Alih Fungsi Lahan Sawah di Kecamatan Tompaso Baru}

Faktor penyebab terjadinya alih funsi lahan di Kecamatan Tompaso Baru meliputi ketersediaan air, faktor ekonomi dan kebijakan.

\section{Ketersediaan Air}

Ketersediaan air menjadi salah satu penunjang keberhasilan usahatani padi sawah. Kurangnya ketersediaan air dapat menyebabkan rusaknya tanaman padi serta gagal panen.

Dari hasil penelitian yang dilakukan di Kecamatan Tompaso Baru, sebagian responden mengalih fungsikan lahan sawah milik mereka sejak tahun 2014. Musim kemarau panjang yang terjadi pada tahun 2014 berdampak pada berkurangnya ketersediaan air di Kecamatan Tompaso Baru sehingga tidak memungkinkan untuk usahatani padi sawah. Jika tetap mengusahakan usahatani padi sawah, petani 
akan mengalami kerugian yang besar. Untuk menghindari hal tersebut mereka lebih memilih mengalih fungsikan lahan sawah mereka menjadi ladang yang tidak terlalu banyak bergantung pada ketersediaan air. Selain itu, akibat rendahnya kersediaan air tersebut membuat jaringan irigasi yang ada tidak digunakan dan tidak terawat yang menyebabkan jaringan irigasi tersebut rusak. Rusaknya jaringan irigasi tersebut serta lamanya usaha yang dilakukan untuk perbaikan jaringan irigasi memaksa petani untuk mengalih fungsikan lahan sawah milik mereka sejak awal tahun 2015. Dari data yang diperoleh, awalnya para responden tersebut mengalih fungsikan sawah mereka untuk sementara saja. Namum karena tidak adanya usaha untuk mengatasi masalah ketersediaan air tersebut serta tidak adanya usaha untuk perbaikan jaringan irigasi, alih fungsi yang awalnya hanya sementara, menjadi permanen sampai saat ini.

\section{Faktor Ekonomi}

Faktor ekonomi yang menjadi penyebab terjadinya alih funsi lahan di Kecamatan Tompaso Baru meliputi rendahnya pendapatan usahatani, dan harga jual lahan.

a. Rendahnya Pendapatan Usahatani

Pendapatan usahatani padi sawah sawah dapat dilihat pada Tabel 8 .

Tabel 8. Penerimaan, Biaya, dan Pendapatan Usahatani Per Musim Tanam

\begin{tabular}{cccc}
\multicolumn{3}{c}{ Per Musim Tanam } & \\
$\begin{array}{c}\text { Luas } \\
\text { Lahan }(\text { Ha) }\end{array}$ & Penerimaan (Rp) & Biaya (Rp) & $\begin{array}{c}\text { Pendapatan } \\
\text { UT (Rp) }\end{array}$ \\
\hline 0.5 & 8.500 .000 & 3.500 .000 & 5.000 .000 \\
1 & 17.000 .000 & 8.000 .000 & 9.000 .000 \\
\hline \multicolumn{2}{l}{ Sumber : Diolah dari data primer 2017} &
\end{tabular}

Tabel 8 menunjukkan pendapatan yang diterima petani dari usahatani padi sawah untuk luasan 0.5 hektar sebesar Rp.5.000.000 per musim tanam atau sebesar Rp.1.250.000 per bulan. Sementara untuk luasan sawah 1 hektar petani menerima pendapatan sebesar Rp.9.000.000 per musim tanam atau sebesar Rp.2.250.000 per bulan. Jika dibandingkan dengan UMR Kabupaten Minahasa Selatan tahun 2017 yang mencapai Rp.2.600.000, pendapatan dari usahatani tersebut dinilai rendah. Bahkan pendapatan dari usahatani tersebut kadang tidak cukup untuk kebutuhan sehari-hari serta biaya untuk kebutuhan sekolah dari anak mereka. Selain itu, biaya yang dikeluarkan untuk usahatani padi sawah juga dinilai cukup tinggi. Bahkan untuk menutupi biaya yang harus dikeluarkan untuk usahatani tersebut, beberapa petani harus melakukan pinjaman ke bank, kerabat, atau koperasi. Hal tersebut mendorong petani untuk mengalih fungsikan lahan mereka. Beberapa petani memilih tidak lagi berusahatani padi sawah dan membangun tempat penggilingan padi di lahan sawah yang mereka miliki. Dari hasil penggilingan padi tersebut pendapatan mereka meningkat sebesar Rp.1.500.000 sampai Rp.2.500.000. Ada juga petani yang menjadikan sebagian lahan sawah yang dimiliki sebagai kolam ikan untuk meningkatkan pendapatan mereka. Dari hasil kolam ikan tersebut pendapatan petani meningkat sebesar Rp.1.000.000 sampai Rp.2.000.000.

b. Harga Jual Lahan

Harga jual lahan untuk sektor non pertanian cenderung selalu mengalami peningkatan seiring berjalannya waktu. Hal ini dipengaruhi oleh peningkatan jumlah penduduk dari tahun ketahun yang berdampak pada meningkatnya kebutuhan lahan untuk pemukiman, kegiatan usaha, dan lain sebagainya sementara lahan yang tersedia jumlahnya tetap. Meningkatnya harga jual lahan serta keuntungan yang bisa didapatkan dengan singkat ketika menjual lahan sawah menjadi pendorong petani untuk menjual lahan sawah yang dimiliki.

Data yang diperoleh menunjukan lahan sawah yang mereka miliki di jual dengan harga Rp.25.000.000 sampai Rp.35.000.000 secara kavlingan untuk pemukiman dengan luasan $11 \mathrm{~m}^{2} \times 30 \mathrm{~m}^{2}$ $\left(330 \mathrm{~m}^{2}\right)$ atau Rp.75.758 sampai Rp.106.061 per $1 \mathrm{~m}^{2}$. Jika dihitung perhektar, keuntungan yang didapat petani dapat dilihat pada Tabel 9.

Tabel 9. Hasil Penjualan Lahan Sawah Menurut Luas dan

\begin{tabular}{|c|c|c|c|}
\hline \multicolumn{3}{|c|}{ Harga Jual } & \multirow[b]{2}{*}{$\begin{array}{l}\text { Total Penjualar } \\
\text { (Rp) }\end{array}$} \\
\hline $\begin{array}{l}\text { Luas } \\
\text { Lahan } \\
\text { (ha) }\end{array}$ & Kavlingan & Harga Jual (Rp) & \\
\hline 1 & 30 & $\begin{array}{l}25.000 .000 \\
35.000 .000\end{array}$ & $\begin{array}{c}750.000 .000 \\
1.050 .000000\end{array}$ \\
\hline
\end{tabular}

Tabel 9 menunjukkan bahwa keuntungan yang diperoleh petani dari penjualan lahan sawah cukup besar yaitu Rp.750.000.000/ha sampai Rp.1.050.000.000/ ha. 


\section{Kebijakan}

Kebijakan pemerintah yang lebih mengutamakan sektor lain di bandingkan sektor pertanian dalam pembangunan kadang menimbulkan masalah dan kerugian bagi para petani. Berdasarkan data yang diperoleh dari penelitian di Kecamatan Tompaso Baru, pemerintah mengeluarkan kebijakan untuk melakukan perluasan pasar. Kebijakan tersebut membutuhkan lahan yang lumayan luas, sementara lokasi pasar yang berdekatan dengan lahan sawah menyebabkan lahan yang harus digunakan untuk perluasan pasar adalah lahan sawah tersebut. Petani yang lahan sawahnya berdekatan dengan lokasi pasar harus merelakan lahan sawah miliknya dijual ke pihak pemerintah dengan harga Rp.400.000.000/ hektar. Kebijakan tersebut jelas menunjukan bahwa pemerintah tidak terlalu mengutamakan sektor pertanian dalam pembangunan ekonomi.

\section{Faktor Dominan Penyebab Alih Fungsi Lahan Sawah di Kecamatan Tompaso Baru}

Faktor dominan atau faktor utama yang menjadi penyebab responden mengalih fungsikan lahan sawah yang dimilikinya dapat dilihat pada Tabel 10 .

\begin{tabular}{|c|c|c|c|c|}
\hline & $\begin{array}{l}\text { Jumlah Resp } \\
\text { Sawah } \\
\end{array}$ & len Menurut & or Penyeba & Fungsi Lahan \\
\hline No & $\begin{array}{c}\text { Faktor } \\
\text { Penyebab }\end{array}$ & $\begin{array}{c}\text { Jumlah } \\
\text { Responden } \\
\text { (orang) } \\
\end{array}$ & $\begin{array}{l}\text { Luas Lahan } \\
\text { (ha) }\end{array}$ & Alih Fungsi \\
\hline 1 & $\begin{array}{c}\text { Rendahnya } \\
\text { Pendapatan } \\
\text { Usahatani }\end{array}$ & 9 & 4,45 & $\begin{array}{l}\text { Penggilingan } \\
\text { Padi } \\
\text { Kolam Ikan }\end{array}$ \\
\hline 2 & Harga Jual Lahan & 8 & 5,1 & Pemukiman \\
\hline 3 & Ketersediaan Air & 24 & 16,95 & Ladang \\
\hline 4 & Kebijakan & 1 & 1 & Perluasan Pasar \\
\hline \multicolumn{2}{|r|}{ Jumlah } & 42 & 27,5 & \\
\hline
\end{tabular}

Tabel 10 menunjukkan bahwa sebanyak 24 orang responden mengalih fungsikan lahan sawah yang dimiliki karena faktor ketersediaan air. Faktor tersebut sangat berpengaruh terhadap proses produksi usahatani padi sawah yang sangat bergantung pada ketersediaan dan kelancaran air. Jumlah responden yang menjadikan faktor tersebut sebagai alasan mereka mengalih fungsikan lahan sawah mereka melebihi setengah dari jumlah keseluruhan responden, sehingga menjadikan faktor tersebut sebagai faktor dominan/utama penyebab alih fungsi lahan sawah di Kecamatan Tompaso Baru.

\section{KESIMPULAN DAN SARAN}

\section{Kesimpulan}

Faktor utama atau faktor dominan yang menjadi penyebab petani melakukan alih fungsi lahan sawah di Kecamatan Tompaso Baru adalah faktor ketersediaan air, serta beberapa faktor lainnya yaitu rendahnya pendapatan usahatani, harga jual lahan, dan kebujakan.

\section{Saran}

Seharusnya pemerintah lebih memperhatikan alih fungsi lahan sawah, serta masalah-masalah yang dihadapi oleh para petani. Tindakan untuk menanggulangi alih fungsi lahan sawah harus segera dilakukan agar alih fungsi lahan sawah yang terjadi tidak meluas. Beberapa langkah yang dapat dilakukan adalah dengan memperbaiki jaringan-jaringan irigasi yang rusak serta membantu dalam hal kersediaan pupuk.

\section{DAFTAR PUSTAKA}

Direktorat Jenderal Prasarana dan Sarana Pertanian, 2013. Cetak Sawah Indonesia.

Hidayati dan Kinseng, 2013. Konversi Lahan Pertanian dan Sikap Petani di Desa Cihideung Ilir Kabupaten Bogor. ISSN : 2302-7571, Vol 4, No 1.

Saleh E, dkk, 2012. Budidaya Padi Dalam Polibeg Dengan Irigasi Bertekanan Untuk Antisipasi Pesatnya Perubahan Fungsi Lahan Sawah. Jurnal Teknotan. ISSN : 1978-1067. Vol 6, No 1.

Sunartomo A. D., 2015. Perkembangan Konversi Lahan Pertanian di Kabupaten Jember. Jurnal Agriekonomika. ISSN: 2301-9948, Vol 01, No 03. 